\title{
Biopharmaceutical characterization of topical liposome formulations bearing 5-fluorouracil
}

\author{
Marija Glavas-Dodov1*, Emilija Fredro-Kumbaradzi1 ${ }^{1}$, Sema Calis ${ }^{2}$, \\ Katerina Goracinova1, Kristina Mladenovska ${ }^{1}$, Maja Simonoska1 ${ }^{1}$, Atila A. Hincal ${ }^{2}$ \\ ${ }^{1}$ Department of Pharmaceutical Technology, Faculty of Pharmacy, University "Ss Cyril and Methodius" \\ Vodnjanska 17, 1000 Skopje, Macedonia \\ ${ }^{2}$ Department of Pharmaceutical Technology, Faculty of Pharmacy, Hacettepe University, Ankara, Turkey
}

Received March 2003; accepted August 2003

\begin{abstract}
Liposome dispersions and liposome gel formulations for topical administration were evaluated as modified release delivery systems for 5-fluorouracil. Drug substance has been entrapped in the internal aqueous compartment of liposomes during the preparation. The concentration of 5-fluorouracil in the hydration medium was varied and the effect on the liposome characteristics was considered. Liposome gel formulations were prepared by incorporation of liophylized liposomes into a structured vehicle of chitosan. The decrease of the amount of aqueous phase bearing total drug quantity (drug/aqueous phase ratio from 1:100, 1:60, 1:40) led to an increase of the percentage of liposome-entrapped drug, and decreased percentage of drug release, while particle size analysis showed no changes in vesicle size. Liposome gel formulations showed initially a higher drug release rate in comparision with liposome dispersions, which could be related to the release of "free" 5-fluorouracil, leaked from liposomes due to the process of liophylization. This was followed by slower release (after 1.5 hour) as a result of the influence of the viscosity of the gel matrix.
\end{abstract}

Key words: liposomes, hydration conditions, topical application, drug release.

\section{Introduction}

In recent years liposomes (phospholipid bilayer vesicles) have attracted increasing attention as a novel drug delivery system for a variety of drugs such as anticancer, antifungal, anaesthetic and antibiotic agents (1-3). With regard to the topical application, liposomes may serve as rate-limiting membrane barriers for modulation of systemic absorption, penetration enhancers or microreservoirs for sustained and controlled release of encapsulated drug (4-8). Topical liposome formulations (as dispersions or hydrogels) could be more effective and less toxic than the conventional topical formulations $(9,10)$. This potential advantage is especially of great interest in topical application of highly toxic drugs, such as antineoplastics.

5-fluorouracil is one of the most effective antineoplastic agent used for treatment of variety of tumours in many

E-mail: magl@baba.ff.ukim.edu.mk

Phone ++389 2 126032; fax: ++389 2123054 organs. Also, it is used topically in the treatment of different skin carcinomas $(11,12)$. Having in mind that liposomes as drug carriers may provide controlled drug release, site-directed and site-avoiding delivery (13), the encapsulation of 5-FU in topical liposome formulation is a reasonable approach for improvement of drug effectiveness and reduction of the side - effects.

Considering the above-mentioned, the aim of our study was to prepare and evaluate liposome formulations with 5-fluorouracil intended for topical application. The effect of the hydration conditions on the physical and biopharmaceutical properties of the prepared formulations has also been considered. In order to determine physical properties of the prepared liposomes as a function of different hydration conditions, microscopic study, particle size analysis and determination of the encapsulation efficiency were carried out. Also, drug release studies from liposome dispersions and corresponding liposome gel formulations were performed to follow the effect of hydration conditions and the influence of gel matrix over the release profile of 5-fluorouracil. 


\section{Materials and methods}

\section{Materials}

For the preparation of liposomes and topical gel formulations, the following materials were used: Phospholipon $90 \mathrm{H}$ - gel state (PL 90H, Natterman Phospholipid, Germany), cholesterol (CHOL, Galenika, Yugoslavia), 5-fluorouracil (5-FU, Ebewe Arzneimittel, Austria), chitosan (Katakura Chikkarin, Japan) and saccharose (Merck, Germany). All other used chemicals were of analytical grade.

\section{Preparation and characterization of liposomes}

Liposomes containing 5-FU were prepared by the modified lipid film hydration method (14). The lipid components, PL 90H and CHOL, were dissolved in chloroform and the organic solvent was removed by evaporation under vacuum $\left(65^{\circ} \mathrm{C}\right)$. Afterwards, the dried lipid film was hydrated with different quantities of aqueous phase bearing total drug quantity (5-FU in phosphate buffer $\mathrm{pH} 7.4$ ), samples LD1, LD2 and LD3, respectively (Table 1).

Table 1. Formulations of liposomes

\begin{tabular}{cccc}
\hline \hline Samples & LD1 & LD2 & LD3 \\
\hline $\begin{array}{c}\text { Lipid phase composition } \\
\text { PL 90H : CHOL }\end{array}$ & $12: 1$ & $12: 1$ & $12: 1$ \\
\hline $\begin{array}{c}\text { Hydration conditions } \\
\text { Mass ratio lipid/aqueous phase } \\
\text { PL 90H-CHOL/phosphate buffer } \\
\text { pH 7.4 }\end{array}$ & $1: 31.3$ & $1: 18.8$ & $1: 12.5$ \\
\hline Mass ratio drug/aqueous phase & $1: 100$ & $1: 60$ & $1: 40$ \\
\hline $1 \%$ Chitosan gel base & LG1 & LG2 & LG3 \\
\hline
\end{tabular}

After $24 \mathrm{~h}$, in order to remove an unentrapped portion of the drug substance, liposomes were washed with phosphate buffer pH 7.4 and ultracentrifuged (20000 rpm, $45 \mathrm{~min}$., 3 times; Ultracentrifuge MLW K24D, Yugoslavia). Liposomes were lyophilized (temperature $-40^{\circ} \mathrm{C}$, pressure $200 \mathrm{~Pa}$; Crist alpha 2-4, Bioblock, Scientific, France) using saccharose as a cryoprotector, incorporated on both sides of the phospholipid lamellae (lipid phase:saccharose $=1: 1.25$ ).

Liposome gel formulations (LG1, LG2, LG3) intended for topical application, were prepared by incorporation of lyophilized liposomes (series LD1, LD2 and LD3) in structured vehicle of chitosan $(1 \% \mathrm{~m} / \mathrm{m})$ in ratio 1:3.

Photomicrographs (standard microscope with camera Nikon, Japan; method by Nomarsky, magnification x600) were taken immediately after the preparation, after dilution with phosphate buffer $\mathrm{pH} 7.4$ (1:1). Particle size analysis was carried out by use of laser difractometry (Fritsch particle size analysette D LAB/22, France).
The encapsulation efficiency of 5-FU in liposomes was quantified UV spectrophotometrically (266 nm; Perkin Elmer, Lambda 16, USA) after dissolving of liposomes in chloroform:methanol mixture.

\section{In vitro dissolution studies}

Release of the drug substance from freshly prepared liposome dispersions and liposome gel formulations was followed in vitro using dialysis through hydrophilic membrane of regenerated cellulose against phosphate buffer $\mathrm{pH}$ 7.4 at $37{ }^{\circ} \mathrm{C}$. Quantity of the released 5-FU in dialyzing medium, within a period of $8 \mathrm{~h}$, was analysed spectrophotometrically. All experiments were carried out in triplicate and average values are presented. To deduce the mechanism of the drug release from the prepared formulations, the release data were mathematically processed.

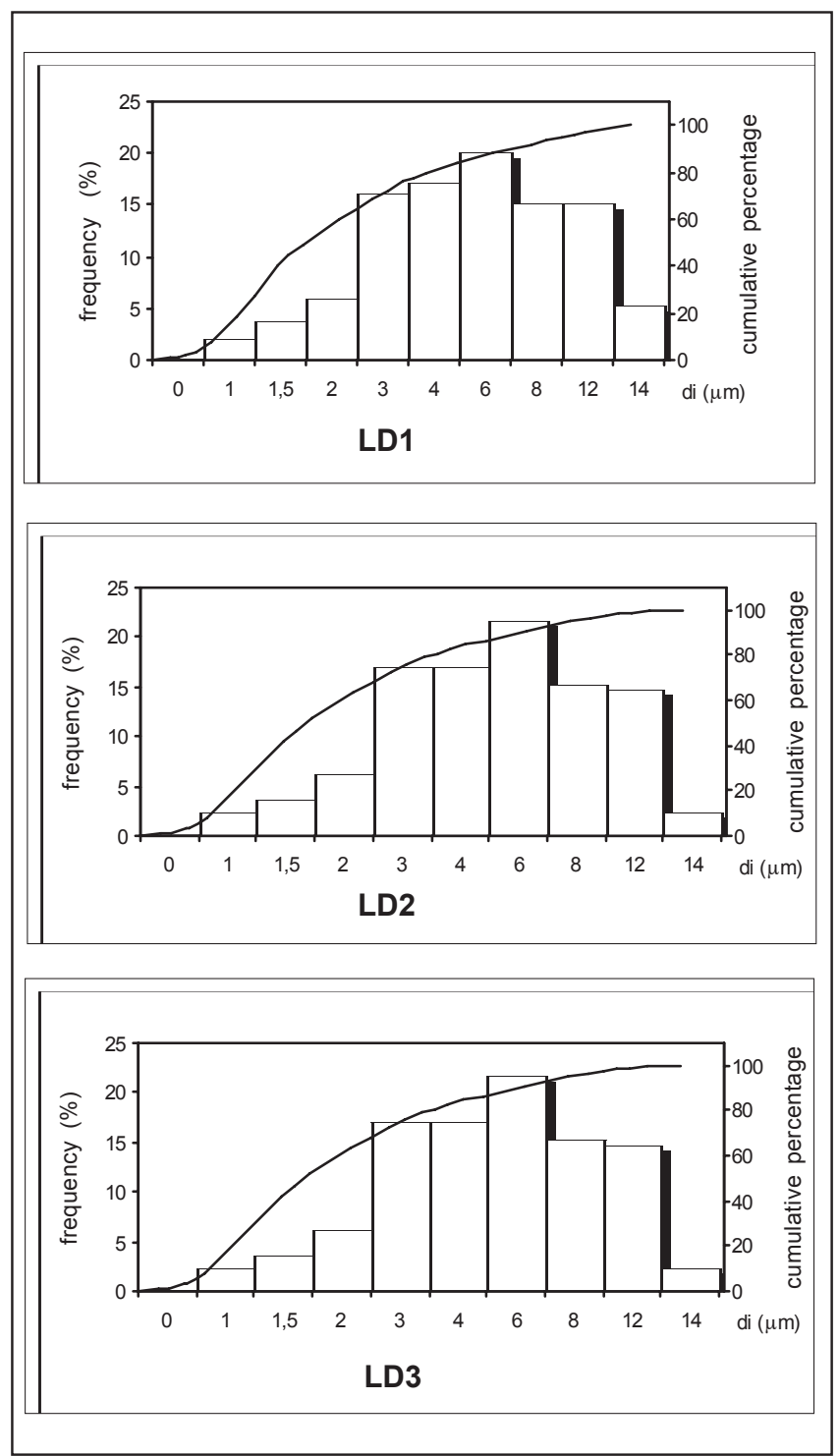

Fig. 1. Particle size-frequency distribution curves and cumulative distribution plots for samples LD1, LD2 and LD3 


\section{Results and discussion}

\section{Characterization of liposomes}

Microscopic observations confirmed formation of spherical vesicles with average size of $5 \mu \mathrm{m}$. The size-frequency distribution curves and cumulative distribution plots for the prepared formulations are presented in Fig. 1.

By varying the drug/aqueous phase mass ratio during the preparation of liposomes, different efficiency of 5-FU encapsulation has been achieved. Lower concentration of the drug substance in the hydration medium resulted in lower incorporation efficiency. At a concentration of $10 \mathrm{mg} / \mathrm{ml}, 16.66 \mathrm{mg} / \mathrm{ml}$ and $25 \mathrm{mg} / \mathrm{ml}$ of 5 -FU in hydration medium (samples LD1, LD2, LD3), the efficiency of 5- FU encapsulation was 5.2, 9.4 and $15.4 \%$, respectively (Fig. 2). The encapsulation of hydrophilic drug substance into

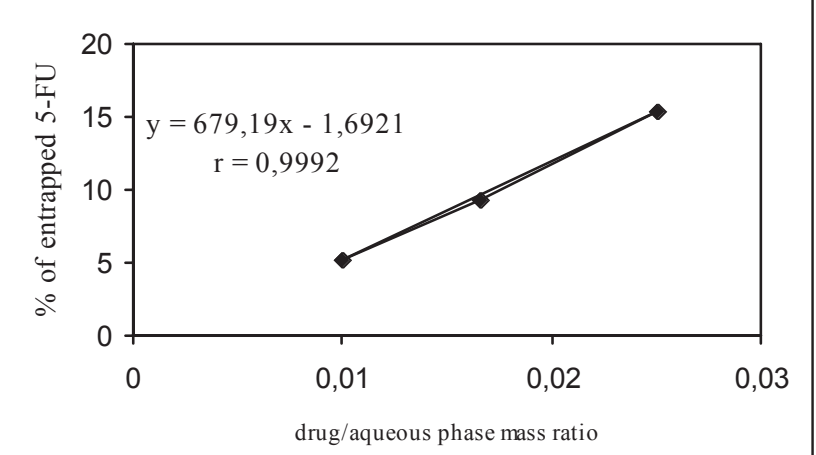

Fig. 2. Effect of hydration conditions on the percentage of incorporated 5-FU into liposomes

liposomes bears relationship to the overall volume of aqueous phase that is encapsulated during liposome formation (15). Having in mind that the prepared vesicles are of similar size (mean geometric diameters were $5.04( \pm 2.01)$, $4.53( \pm 2.02)$ and $4.75 \mu \mathrm{m}( \pm 1.89)$ for samples LD1, LD2 and LD3 respectively), higher encapsulation efficiency of 5-FU into liposomes could be related to the higher drug concentration in the hydration medium.

\section{Drug release from liposome dispersions and liposome gel formulations}

Drug releases from liposome dispersions are presented in Fig. 3a. As it can be seen, by increasing the drug/aqueous phase mass ratio (from 1:100, 1:60, 1:40), the release rate of 5-FU decreased. Bearing in mind the percentage of liposome-encapsulated 5-FU, it is obvious that formulations with higher percentage of encapsulated drug showed slower release rate. This may suggest that liposome bilayer acts as a rate-limiting membrane barrier for the release of encapsulated drug substance.

The release of 5-FU from liposome gel formulations was found to be a function of liposome characteristics and prop-

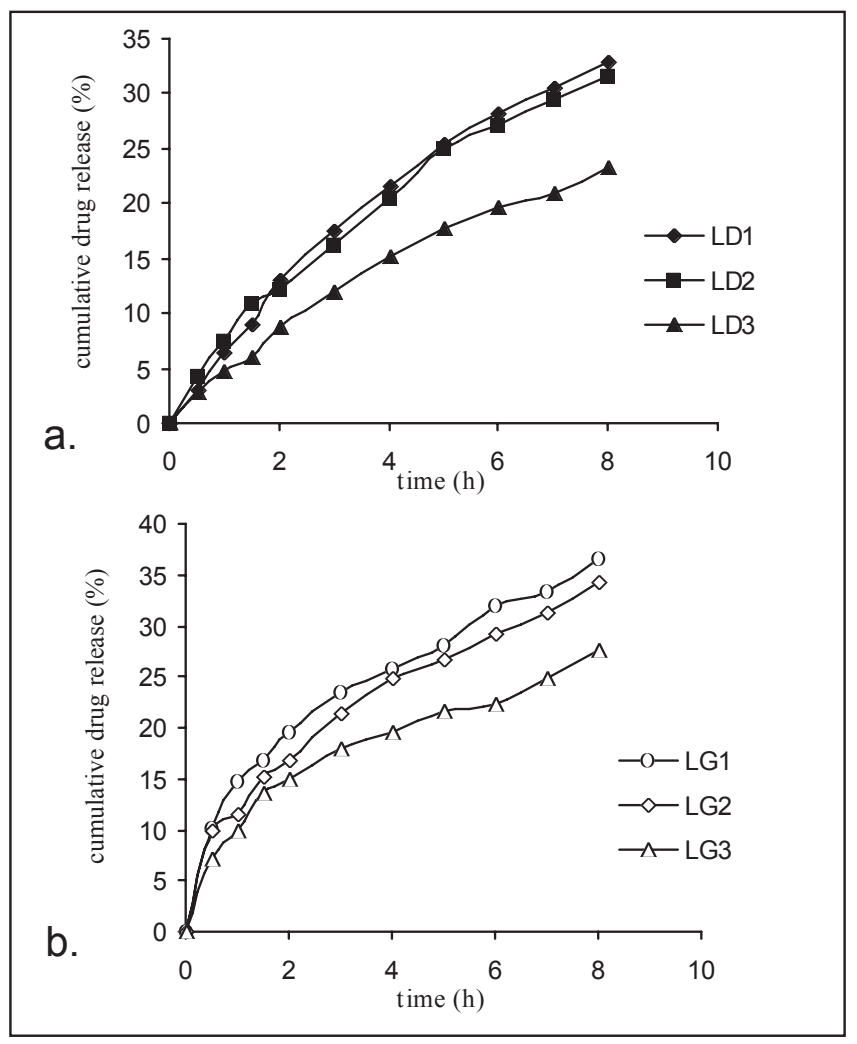

Fig. 3. Release of 5-FU from liposome dispersions and liposome gel formulations, $n=3$

erties of the gel matrix. Gel liposome formulations (Fig. 3b) showed initially faster release rate (first 1.5 hours) compared to corresponding liposome dispersions, followed by a continuous much slower release rate. The release pattern during the first 1.5 hour could be related to the portion of drug substance that leaked out of liposomes during the process of lyophilization $(1,16)$. Slower release rate after 1.5 hour correlates to the release of liposome entrapped 5-FU and the influence of the viscosity of the gel matrix.

To examine the mechanism of the release of 5-FU from liposome dispersions and liposome gel formulations, the Higuchi diffusion model and zero order kinetic were applied. Kinetic data indicated that the release of 5-FU followed the diffusion model of Higuchi (rate constant $k=8.55-14.47 \% \mathrm{~h}^{-1 / 2}$

Table 2. Release rate constants for the prepared formulations $(r>0.985)$

\begin{tabular}{cccc}
\hline \hline Samples & $\begin{array}{c}\text { Diffusion } \\
\text { model } \\
\mathrm{k}\left(\% \mathrm{~h}^{-1 / 2}\right)\end{array}$ & $\begin{array}{c}\text { Diffusion } \\
\text { model } * \\
\mathrm{k}\left(\% \mathrm{~h}^{-1 / 2}\right)\end{array}$ & $\begin{array}{c}\text { Zero order } \\
\text { kinetic } * * \\
\mathrm{k}\left(\% \mathrm{~h}^{-1}\right)\end{array}$ \\
\hline LD1 & 14.47 & - & 3.29 \\
LD2 & 13.17 & - & 3.22 \\
LD3 & 8.55 & - & 2.00 \\
LG1 & 11.90 & 13.10 & 2.89 \\
LG2 & 11.68 & 9.98 & 2.87 \\
LG3 & 11.61 & 11.39 & 2.85 \\
\hline * $0-1.5$ hour & & & \\
$* *$ after 1.5 hour & & &
\end{tabular}


for liposome dispersions and $k=11.61-11.90 \% \mathrm{~h}^{-1 / 2}$ for liposome gel formulations), while the release rate after 1.5 hour obeyed the zero order kinetic (rate constant $k=2-3.29 \% \mathrm{~h}^{-1}$ for liposome dispersions and $k=2.85-2.89 \% \mathrm{~h}^{-1}$ for liposome gel formulations) (Table 2). This may suggest that liposome vesicles act as a reservoir system for controlled release of encapsulated drug substance 5-FU.

\section{Conclusion}

As a conclusion, incorporation of aqueous solution of 5-FU into a lipid mixture of phospholipid PL $90 \mathrm{H}$ and cholesterol under the proposed hydration conditions, enable formation of liposomes with a potential use as a sustained release depot. Incorporation of liposomes bearing 5-FU into a structured vehicle of chitosan provided formulations suitable for topical application.

\section{References}

1. D.J.A. Crommelin and K. Schreier, in Colloidal drug delivery systems, J. Kreuter, Ed., Marcel Dekker New York, 1994, pp 73-123.

2. R. Singh and S. P. Vyas, J. Dermatol. Sci., 13, 107-111 (1996).
3. G. Lopez-Berestein and E. J. Fidler, Liposomes in the therapy of infection diseases and cancer, New York Liss, 1989.

4. M. H. Schmid and H. C. Korting, Adv. Drug Deliv. Rev., 18, 335-342 (1996).

5. K. Egabaria and N. Weiner, Adv. Drug Deliv. Rev., 5, 287-300 (1999).

6. N. Skalko, M. Cajkovac and I. Jalsenjak, Int. J. Pharm., 85, 97-101 (1992).

7. M. K. Kim, S. J. Chung, M. H. Lee, A. R. Choy and C. K. Shim, J. Control. Release, 46, 243-251 (1997).

8. V. B. Patel, A. Mirsa and Y. S. Marfatia, AAPS Pharm. Sci. Tech., 3, 56-62 (2001).

9. V. Gabrielcic and M. Sentjuri, Int. J. Pharm., 118, 207-212 (1995).

10. E. Touitou, H. E. Junginger, N. D. Weiner, T. Nagai and M. Mezei, J. Pharm. Sci., 83, 1189-1203 (1994).

11. H. Boussen, J. Zwik, I Mili-Boussen, N. Rammeh, N. Bouaouina, S. E. Gritli and A. May, Therapie, 56, 751-754 (2001).

12. M. E. Unis, Dermatology and Surgery, 21, 162-163 (1995).

13. S. B. Kulkarni and G. V. Betageri, in Pharmaceutical particulated carriers, Therapeutical application, A. Rolland, Ed., Marcel Dekker, New York 1993, pp 82-135.

14. A. D. Bangham, J. Mol. Biol., 13, 238-252 (1965).

15. B. Elorza, M. A. Elorza, G. Frutos and J. R. Chantel, Biochim. Biophys. Acta, 1153, 135-142 (1993).

16. Y. Ozer, H. Talsma, D. J. A. Crommelin and A. A. Hincal, Acta Pharm. Technol., 34, 133-139 (1989).

\title{
Резиме
}

\section{Биофармацевтска карактеризација на липозоми со енкапсулиран 5-флуороурацил за дермална примена}

\author{
Марија Главаш-Додов¹, Емилија Фредро-Кумбараџиํ, Сема Чалис²,

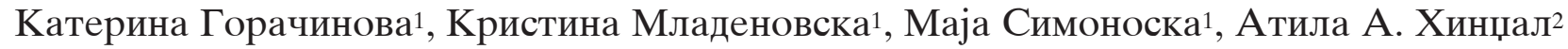

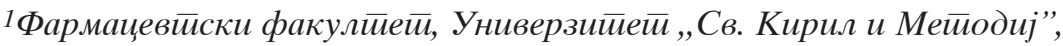 \\ Водњанска 17, МК-1000 Скойје, Рейублика Македонија

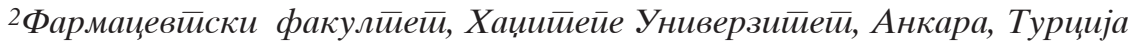

Клучни зборови: липозоми, услови на хидрирање, дермална примена, осободување на лековитата супстанција.

Со користење на модифицирана техника на хидрирање на липиден филм подготвени беа различни формулации на липозомски дисперзии со вградена хидрофилна лековита супстанција 5-флуороурацил. Со цел да се согледа влијанието на различните пристапи во подготовката на липозомите, како и да се определи нивната потенцијална примена како депоа за продолжено ослободување на вградената лековита супстанција, формулациите беа подготвени под различни услови на хидрирање на липидниот филм (однос лек/водена фаза) и беа инкорпорирани во цитозански гел матрикс.

Со варирање на количината на водена фаза во која е растворена лековитата супстанција беше постигната различна ефикасност на енкапсулација на 5-флуороурацилот, при што намалувањето на количеството на водена фаза во која е растворен 5-флуороурацилот (масен однос лек/водена фаза), резултираше со повисока ефикасност на енкапсулација.

In vitro следењето на брзината на ослободување на лековитата супстанција од липозомските дисперзии и гел липозомските формулации покажа дека гел липозомските формулации во споредба со соодветните липозомски дисперзии даваат поголем процент на иницијално ослободена лековита супстанција. Ова може да се припише на процесот на лиофилизација на липозомите, која неминовно доведува до оштетување на дел од везикулите, проследено со излегување на дел од лековитата супстанција надвор од везикулите. Во понатамошниот тек на ослободувањето, брзината на ослободување на 5-флуороурацил од гел липозомските формулации не покажа поголеми разлики во однос на липозомските дисперзии.

Математичката обработка на резулататите од ослободувањето на вградената лековита супстанција од липозомските дисперзии и гел липозомските формулации покажаа дека ослободувањето го следи моделот на дифузија. Истовремено по 1.5 часа, ослободувањето ја следи кинетиката од нулти ред што ја потврдува можноста на липозомските везикули да функционираат како депоа на лековитата супстанција од каде таа може контролирано и успорено да биде ослободена. 